\title{
What are people talking about in moral outrage? Communication processes of online firestorms in Japan
}

\author{
¿De qué habla la gente ante la indignación moral? Procesos de \\ comunicación de online firestorms en Japón
}

Kato, H. ${ }^{1}$

Recibido: 10-10-2019 - Aceptado: 15-02-2020

DOI: https://doi.org/10.26441/RC19.1-2020-A12

\begin{abstract}
In the age of the Internet, anonymous online users can form a societal reaction by posting large quantities of critique and insulting comments against (perceived) norm violations on social media. These so-called online firestorms, or Enjō in Japanese, tend to include aggressive behavior against the target. This research aims to reveal the dynamics of Enjō and explores how people communicate with each other in the formation process of Enjō by conducting a comparative case study. This study collects tweets posted in five Enjo cases and compares each case to create conceptual categories of the communication process of Enjō. Results show that the participants of Enjō interact with each other to define the problem of concern through exchange of information. Moreover, it is revealed that there are two types of process in the escalation of Enjo, "social problematization" and "villainization." In the conclusion, the implications of these findings are discussed.
\end{abstract}

Keywords: online firestorms; social media; aggressive comment; collective communication; Enjō.

RESUMEN: En la era de Internet, los usuarios anónimos en línea pueden formar una reacción social al publicar grandes cantidades de críticas y comentarios insultantes, esto se considera violación de normas de etiqueta de las redes sociales. Estas llamadas online firestorms, o Enjō en japonés, tienden a incluir un comportamiento agresivo contra el objetivo de las mismas. Esta investigación tiene como objetivo revelar la dinámica de Enjō y explora cómo las personas se comunican entre sí en el proceso de formación de Enjō mediante la realización de un estudio de caso comparativo. Este estudio recopila tweets publicados en cinco casos de Enjō y compara cada caso para crear categorías conceptuales del proceso de comunicación de Enjō. Los resultados muestran que los participantes de Enjō interactúan entre sí para definir el problema de interés a través del intercambio de información. Además, se revela que hay dos tipos de procesos en la escalada de Enjō, "problematización social" y "villano". En conclusión, se discuten las implicaciones de estos hallazgos.

Palabras clave: online firestorms; redes sociales; comentarios agresivos; comunicación colectiva.

\footnotetext{
${ }^{1}$ Hiroki Kato is a Ph.D. Candidate in Sociology and Communication studies of the Graduate School of Interdisciplinary Information Studies at the University of Tokyo. d.vnc415@gmail.com, https://orcid.org/0000-0003-09814716
} 


\section{Introduction ${ }^{2}$}

Every social group develops peculiar rules such as laws and tacit norms to organize cooperative social life, and at the same time, generates deviance by collectively criticizing and sanctioning those who violate them (Becker, 1963; Durkheim, 1978). Such societal reactions, or collective communication to label a subject (an affair) as immoral or problematic, are constructed formally or informally (Hogetsu, 2004). For example, the former includes policing and sanctioning of criminal behavior by social control agencies such as the police and courts and the construction of social problems by the legislature and mass media. On the other hand, the later indicates non-institutional, unspecialized labelling processes such as scolding a child at home and criticizing an outsider in a local community. Such reactions found in any society have a function to identify the boundary of a social group because it allows its members to bond emotionally and reconfirm its rules (Durkheim, 1978; Erikson, 1966).

This ubiquitous phenomenon has also been observed on the Internet since the advent of Web 2.0. In other words, anonymous online users can participate in informal societal reactions by posting large quantities of critique and aggressive comments against perceived norm violations on social media, which is called online firestorming or Enjo in Japanese. Though this concept is similar to 'flaming' and 'trolling,' it differs from them to the extent that it represents collective communication in which many of the online participants ${ }^{3}$ upload comments to criticize a problematic affair and maintain order (Yamaguchi, 2017), whereas flaming could be described as one-to-one interaction (Tanaka \& Yamaguchi, 2016) and trolling could be defined as destructive or disruptive communication without instrumental purpose (Buckels, Trapnell, \& Paulhus, 2014). Such Enjō phenomena frequently occur in the current digital environment. Some reports show that, in recent years, incidents of Enjo happen more than twice a day in Japan (eltes, 2017; NHK, 2017) and another survey reveals that approximately 80 percent of the respondents recognize the term 'Enjo,' suggesting that it has become prominent since its emergence (Yoshino, 2016). These reports indicate that Enjo is a mundane event that is embedded in everyday social interaction on the Internet.

While Enjō can facilitate the rising of a social issue which might have been ignored without social media, it is likely to go out of control and cause abusive insults to its target. Due to such a negative aspect, many researchers consider Enjō as a pathology in society and some call it 'social bullying' or 'online lynching' (Kawakami, 2014; Nakagawa, 2010; Ogiue, 2007). It has actually led to some serious problems. For instance, anonymous bashing on SNS or online bulletin boards toward a celebrity or even a lay person can cause such serious mental damage that the target may commit suicide. In addition, the dissemination of negative reputations by online bashing can damage the target firms economically leading to a decrease in their stock prices (Adachi \& Takeda, 2016). Enjo has huge negative impact on individuals and organizations and therefore is an urgent issue to be empirically tackled.

The existing research has investigated aggressive communicative behavior in CMC (Computer-Mediated Communication) and the attributes of the participants, but it is limited to the extent that it cannot explain the dynamics of Enjō. To overcome this limitation, this article focuses on collective online communication among those who are involved in Enjō phenomena. This study collected and

\footnotetext{
${ }^{2}$ This article was presented at the Working Group of Ethics of the Society and Ethics of Communication of the International Association of Media and Communication Research (IAMCR) during the congress held in Madrid from July 7 to 11, 2019. The full text was selected among the best papers of the edition and proposed for publication to the Editorial Board of the Revista de Comunicación by the Heads of the Working Group -Chair Teresa Nicolás Gavilán and Vice-chair Elvira García de Torres.

3 Those who post comments or share information in Enjō cases are henceforth referred to in this paper as "participant(s)."
} 
analyzed tweets posted in five Enjō cases and conducted a comparative case study to inductively generate abstract, systematic categories of communication processes from the data. Overall, the findings show that Enjo participants exchange among themselves information and opinions about what and whom to attack. The findings also reveal that they do not only discuss the criticized event itself, but also talk about other related topics derived from that discussion. These findings have important implications for our understanding of Enjo and for practical issues such as how to control its dynamics.

\section{Reference framework}

\subsection{The online environment and violent behavior}

There are many studies which examine the relationship between aggressive communicative behavior and the attributes of the online environment such as anonymity. Such Research is based on the premise that the characteristics of CMC, which differs from face-to-face interaction in some respects, influence individual's psychology or group dynamics and lead to types of behavior which are not usually observed offline.

For instance, some research explains online flaming by reduced social cues caused by anonymity in CMC. When a person who sends a message is unidentifiable to others, which is called self-anonymity (Scott, 1998), there is a lack of personalized social cues such as age, sex, and social position. Reduced social cues then release him/her from responsibility and cause uninhibited, socially undesirable behavior such as offensive communication (Kiesler, Siegel, \& McGuire, 1984; Sproull $\&$ Kiesler, 1986). This theoretical framework stems from previous research on the effect of de-individuation, which reveals that the less individuals are identifiable, the more they show extra- or anti-normative behavior (Zimbardo, 1969).

Though this model presents rational explanation about the influence of online anonymity on human behavior, it cannot apply to Enjo phenomena considering that the above-mentioned survey shows that the participants of Enjo are motivated by indignation toward the violation of a social norm, which suggests that they are still oriented to maintain order and social norms (Miura, 2010). Many researchers therefore employ another model, which is called the Social Identity model of De-individuation Effect (the SIDE model), to explain the formation of Enjō (Korenaga, 2008; Miura, 2010; Morio, 2009). This model also proposes that online anonymity can cause violent behavior, but the psychological mechanism behind it is different from those in the previous model in the sense that the SIDE model applies social identity theory to online settings (Reicher, Spears, \& Postmes, 1995; Spears, Lea, \& Postmes, 2007). This theory suggests that the salience of an individual's identity (personal identity or social identity) depends on social contexts (interpersonal contexts or intergroup contexts) and proposes that de-individuation in anonymous settings can increase conformity to a group norm depending on the social context. When the social context implicates people as group members and social identity is salient, for example, de-individuation facilitates people's group identification and in-group normative behavior, eventually leading to polarized opinions. Based on this model, it would be rational to anticipate that, when the majority of group members behave aggressively and offensive behavior becomes a normative behavior, online anonymity can facilitate aggressiveness by enhancing conformity to such a norm.

\subsection{The participants of Enjō}

The theoretical frameworks presented above are well established and would partially explain the formation of Enjo focusing on anonymity in online settings. Nevertheless, the psychological 
models do not provide us complete understanding about the mechanisms of Enjo and further research is necessary to shed light on other aspects of Enjō. In recent years, researchers have tried to reveal the attributes of the participants as surveys show that most people do not post offensive comments even with online anonymity. Tanaka and Yamaguchi (2016), for example, asked approximately 40,000 Internet users about their experience of participating in Enjo through an online survey and found that only 1.5 percent of the respondents had experienced posting some offensive comments about Enjō targets on social media. Other empirical studies have shown similar results and Enjō participants generally seem to amount to between one and three percent of online users.

Based on the results that only a small number of people participate in Enjō, researchers and critics have further discussed and explored their characteristics (Kawakami, 2014; Nakagawa, 2010; Tanaka, 2016; Tanaka \& Yamaguchi, 2016). One of the studies which aim to empirically reveal their traits was carried out by Tanaka and Yamaguchi (2016). They conducted a more detailed survey on 2,020 respondents (including Enjo participants) extracted from the previous one and investigated the attributes and dispositions of the participants, such as sex, age, education, and attitudes toward online communication. This research reflects huge social interest on the characteristics of the participants of Enjō and the dominant social discourse that they are mainly 'losers' who have low education, earn low income, and hate society. Nevertheless, the survey suggested a different situation. The result shows that participation in Enjō significantly correlates with sex, age, the number of children, income, the usage of radio and social media, negative experiences on the Internet, and attitudes toward criticism on the Internet. In other words, the participants of Enjo are likely to be young men with at least one child, who earn high income, frequently use radio and social media, have unpleasant experience on the Internet, and affirmatively evaluate online criticism. These findings imply that they are not 'unsuccessful' people in terms of demographic traits, but rather 'successful' individuals who belong to the middle class in Japan.

\subsection{Enjō as a collective interaction process}

The existing studies have revealed some aspects of Enjo such as the effect of anonymity on its formation and the attributes of the participants. However, they are theoretically limited in that they tend to capture Enjō as a relatively static phenomenon and cannot elucidate its dynamics. One study, for example, collects tweets posted in six Enjo cases and reveals that the amount of tweets ranges from a minimum of 1,850 posts to a maximum of 74,396 posts (Tanaka \& Yamaguchi, 2016). This result implies that the scale of online firestorming drastically changes depending on the case. Moreover, the amount of and the intensity of critical comments vary not only among cases but also within a case. Online jargon such as 'fuel injection' (sudden increase of criticism) and 'extinguishment' (sudden decrease of criticism) suggests that bashing is not static in the formation process of Enjo (Kobayashi, 2011). Of course, the SIDE model can explain how the number of offensive comments toward a norm violation increases because of conformity to a group norm in anonymous online settings. However, it is only applied to the linear amplification of criticism and cannot describe the variety of courses of Enjo in its formation process. So, despite the fact that Enjo phenomena are dynamic, previous research has failed to explain the mechanisms of the change.

To reveal the dynamics of Enjō, this paper considers Enjō as a collective interaction process and investigates communication processes among the participants of Enjō. Some studies show that most comments posted in Enjo do not directly criticize the target but are oriented to interact with other users by writing opinions and sharing information about the event (Tanaka, 2016; Toriumi \& Saka$\mathrm{ki}, 2016)$. This suggests that this kind of collective interaction to exchange opinions and information seems to play an important role in the formation of Enjo phenomena. 
The theoretical background of this research is an interactionist perspective on collective behavior called the emergent norm approach (Turner \& Killian, 1987). Being grounded in symbolic interactionism (Blumer, 1969) and cognitive psychological research on conformity (Asch, 1952; Sherif \& Harvey, 1952), the emergent norm approach proposes that collective behavior is a collective communication process where people constantly form and reform a norm, "a common understanding as to what sort of behavior is expected in the situation" (Turner \& Killian, 1987, p. 26), through the exchange of symbols and act in terms of the norm. When applying this perspective to Enjo phenomena, it is suggested that Enjo is formed through communication among the participants and the course of the event is affected by a shared norm which is constructed through that communication. In other words, Enjō participants continuously interact with each other and develop emergent norms by which participants' behavior is oriented, and changes in those norms vary people's attitudes or the intensity of criticism toward the target. Analysis of communication based on the emergent norm approach, therefore, seems to be beneficial to reveal the dynamics of Enjo.

Based on the discussion about the lack of research on the dynamics of Enjo, this article explores the following research question:

How do the participants communicate with each other in the formation process of Enjō?

\section{Methodology}

To answer the research question presented above, this study conducted a comparative case study on five Enjō cases. A comparative case study is a kind of explorative study, which aims to discover common elements in several cases by comparing them (Sato, 2008). Put differently, its purpose is not to describe and interpret each case in detail but to generate abstract, conceptual categories from data through analyzing similarities and differences among cases. This is the proper method for the current research since previous studies have scarcely investigated communication processes of Enjo and it is necessary, as the first step, to conduct inductive research on them.

The five cases analyzed in this paper were selected based on two criteria. First, the cases were sampled in terms of the richness of the data. To generate comprehensive, sophisticated categories, it is essential to analyze abundant data, which means a large quantity of comments are required. Therefore, this paper selected relatively large-scale cases. Second, the variety of selected cases was an important criterion as well. Based on the idea that analyzing a variety of cases enhances the generalizability of the study, this research selected various cases in terms of the target of criticism, the agenda discussed among the participants, and the course of the event. Table 1 shows some details of the selected five Enjo cases.

Table 1. The Details of the Selected Five Enjō Cases

\begin{tabular}{|c|c|l|l|}
\hline 1 & Date & \multicolumn{1}{|c|}{ Target } & \multicolumn{1}{c|}{ Event } \\
\hline 2 & 2015.03 & $\begin{array}{l}\text { a fashion retail } \\
\text { company }\end{array}$ & The company released a WEB commercial that contained sexual harassment. \\
\hline 3 & 2016.08 & $\begin{array}{l}\text { Shima-city } \\
\text { a PC support } \\
\text { company }\end{array}$ & $\begin{array}{l}\text { Shima-city certified an anime girl character of a female diver as its official } \\
\text { mascot. }\end{array}$ \\
\hline 4 & 2018.02 & $\begin{array}{l}\text { a picture book } \\
\text { computers. } \\
\text { writer }\end{array}$ & $\begin{array}{l}\text { The writer released lyrics that seem to approve an environment oppressive to } \\
\text { mothers. }\end{array}$ \\
\hline 5 & 2018.05 & $\begin{array}{l}\text { college football } \\
\text { coaches }\end{array}$ & $\begin{array}{l}\text { The coaches were suspected of forcing one of the players to make a violent } \\
\text { tackle. }\end{array}$ \\
\hline
\end{tabular}

Author's own creation. 
The collected data are posted tweets in each Enjō case. Though Enjō can occur anywhere on the Internet and we can collect comments from various online platforms such as blogs or online bulletin boards, it is desirable to focus on a specific platform in order to make the conditions of the compared cases uniform. This study chooses Twitter as the research field since Twitter has been the main arena for Enjō phenomena in recent years (NHK, 2017).

The current research collected tweets using an aggregation site called 'Togetter' (https://togetter. $\mathrm{com} /$ ). Togetter is the most popular tweet aggregation site in Japan, where users can create pages on particular topics by collecting related tweets, arranging them in order, and presenting them to the public. There exists, on this site, various aggregation pages on past Enjō cases, and therefore, it enables us to collect a number of, and a variety of Enjo-related tweets. In the collecting process, Enjō-related pages were first identified by searching keywords related to each Enjō case (e.g., the name of the target) on the site. More than five pages per case were selected, and tweets were extracted from these pages. The number of the collected tweets ranges from almost 250 to approximately 900 depending on the case.

To code and interpret the data, this study employed the Grounded Theory Approach (GTA), which aims to inductively generate categories and theories from data (Glaser \& Strauss, 1965, 1967). The analysis was conducted in accordance with the following procedure. The first step is to give each tweet a label briefly summarizing its content. The second step is to create groups of similar labels and generate abstract categories through the comparison of each tweet, label, and case. The analysis was not one-directional but rather a cyclical process proceeding back and forth between the data and the categories in order to create sophisticated categories.

\section{Results}

The following sections explain the patterns of communication, which frequently arise among the participants of Enjo.

\subsection{Definition of the problem}

It is not easy to define what deviance, or problems are. In other words, deviance or problems do not exist independently as objective facts, but they are products of a process of collective communication and social definition. This perspective is grounded in labeling theories in deviance studies (Becker, 1963) and the social construction of social problems (Spector \& Kitsuse, 1977). Drinking, for example, is currently a permitted act for adults in the U.S. but was socially prohibited and illegal in the same country approximately 100 years ago. This example suggests that the boundary between what is socially criticized and what is socially accepted is ambiguous and becomes clear through communication among members of society. People usually interact with each other and confirm that a certain act is deviant or problematic even in cases where it is an obvious violation of the law or social conventions. It is therefore considered that, in societal reactions toward norm violations, communication plays an important role in deciding and confirming what the problem is.

The findings show that this perspective is also applicable to Enjo phenomena, which means that Enjo participants actually communicate with each other to define the problem. This is theoretically reasonable considering that, in informal societal reactions, such as Enjō, where there are no distinct rules, communication among the participants is more likely to be active than in formal societal reactions because people are required to create an improvised definition of the problem on the spot. As shown in the cases analyzed, once a statement that insists on the existence of a problem begins to catch public attention on Twitter, users start discussing or ascertaining whether it is a problem or not by posting their own opinions or information related to the agenda. Through the analysis of the data, this study generated two categories 
of communication, namely 'reconstruction of the event' and 'interpretation of the event.' These categories constitute the interaction processes through which the problem is defined.

\subsubsection{Reconstruction of the event}

'Reconstruction of the event' represents the process of collective communication where people exchange information on the criticized issue and try to grasp the entire picture of the event. In most Enjo cases, the participants are those who accidentally know the event through social media or mass media, which implies that they do not know much about it at the beginning. They are therefore required to first share information and comprehend the details of the event in order to interpret it, and this type of communication is categorized as 'reconstruction of the event.' It is further divided into two subcategories, which are 'verification of the fact' and 'contextualization.'

In 'verification of the fact,' online users aim to ascertain what actually happened through collective interaction. This communication process tends to emerge especially when there is ambiguity on the existence of the problem. In the case 3, for instance, this kind of communication was frequently observed. This Enjo case was triggered by a tweet which contends that a PC support company named PC DEPOT requested the poster's father aged over 80 to pay an especially high cancellation fee. Though many readers reacted to the post with anger and criticized the company, some did not immediately believe the claim of the poster but rather suspected him of lying or misunderstanding. For example, one user replied to the accuser that "the cancellation fee should be appropriate. There should be a reason for such a high cost" (@sakuya_little, 2016,_August 15). Through this kind of communication, users try to understand the details of the event and attain accurate information on it.

On the other hand, 'contextualization' is defined as a collective communication process where people reveal the background of the event and impart contexts to it. When individuals interpret the meaning of an event in general, they do not only evaluate the event itself, but also interpret comprehensive contexts in which the event is embedded. The participants likewise share contexts behind the event through online communication, which help them to interpret and evaluate whether it is problematic or not. The case 2 provides a good example. In this case, online users criticized Shima-city in Mie prefecture for its certification of an anime girl of a female diver as its official mascot. Though the official intended to promote female divers as part of its local, traditional culture to foreign countries, many people claimed that the character was too sexual for the official mascot, it distorted the image of female divers, and it lacked respect for the traditional occupation. An exemplar of 'contextualization' in this case is a tweet like this: "female divers have tended to be described sexually and they have objected to it for a long time. This is not the first case" (@aconitine_NEO, 2015, August 8). This tweet represents a type of communication which shares a historical context on the issue and tries to provide a more comprehensive picture of the event.

\subsubsection{Interpretation of the event}

Another type of communication which forms the definition of the problem is 'interpretation of the event.' In this communication process, the participants share among themselves their opinions and attitudes toward the criticized issue, discussing whether it is problematic and what exactly the problem is. An affair is a complex of innumerable factors and can be interpreted in any way depending on the interpreter's values, beliefs, and point of view. The meaning of the event, therefore, is not fixed in advance but is gradually determined through collective communication among the participants. This interpretive process is deeply related to the process of 'reconstruction of the event' since the later provides the foundation for the former, which means that online users evaluate an event based on their understanding about it. This category consists of two subcategories, which are "value judgement' and 'assignment of responsibility.' 
First, 'value judgement' represents a type of communication where people collectively confirm what to attack and share how serious the problem is, by focusing on a particular aspect of the event and imparting a negative meaning to it. For instance, there emerged discussion by Twitter users about the services provided by PC DEPOT in the case 3 . While comments such as "this is terrible. PC DEPOT provides excessive services and cheats elderly people, who don't know much about PCs, out of their money" (@hasekiyo2468, 2016, August 15) were dominant on Twitter, some supported the company and posted comments including "I can understand the accuser's claim but I feel that the company's PC support is satisfying and the cost of its services is relatively reasonable" (@) ys5project, 2016, August 15). These tweets represent collective communication where the participants discuss whether or not there is a problem to criticize.

Second, 'assignment of responsibility' is the process of communication where the participants collectively determine whom to attack, by shedding light on a particular person (or organization) who seems to be responsible for the problem. We can see a good example of it in the case 1 . In this case, a famous fashion retail company, LUMINE, was under fire because of one of its WEB commercials, in which a male boss makes fun of the appearance of a female worker and she decides to change and become beautiful. Just after it was released, those who watched it started posting negative comments and claimed that it positively described sexual harassment and the value that women should always care about their appearance. Regarding this problem, a user tweeted: "a commercial of LUMINE is under fire. I feel for its employees who work at shops owned by LUMINE. I know most of them are nice. The management who decided to release the commercial should be blamed for the problem and resign" (@KTB_genki, 2015, March 20). This comment is part of 'assignment of responsibility' in the sense that it distinguishes those who are responsible for the commercial from all employees in LUMINE and identify the management as the target of criticism. Through this kind of communication, Enjō participants define whom to attack.

\subsection{Expansion of the problem}

As discussed in the previous sections, when Enjō occurs, the participants actively communicate with each other to discuss and ascertain whether the event is problematic or not. Nevertheless, they do not only reconstruct and interpret the event, but also talk about other related topics derived from the definition of the problem. In other words, the agenda of collective communication among online users expands beyond the event itself. This process of communication consists of two generated categories; one is 'identification of similar problems' and another is 'background checking of the target.'

\subsubsection{Identification of similar problems}

'Identification of similar problems' represents a process of communication where participants confirm that the problem is not limited to the current topic and there are other similar issues in society. By being informed about an issue through online firestorming, some users remember their experiences of having similar problems and share it with their followers, and accumulation of this kind of communication forms 'identification of similar problems.' In the case 3, where a PC support company was socially blamed for its vicious services, for instance, many Twitter users shared their experiences of being deceived by other companies. The typical comments include the following tweet: "I do not feel that this problem is somebody else's business. Like this one, I have been nearly deceived by a telephone company called So-NET. In that case, I got angry and yelled at a member of staff, but he did not admit his fault" (@shinmk, 2016, August 17).

When many users participate in this type of communication and share similar problems with others, the focus of criticism shifts from an individual case to the condition of society as a whole. Put diffe- 
rently, as people find that they are surrounded by similar problems and society is full of them, individuals begin to consider the issue as a social problem. The case 2, where Shima-city was blamed for certifying an anime girl character as its official mascot, provides a good example. In this case, some users indicated the existence of similar cases and one comment said: "this is not the only case. In Japan, there exist so many sexual anime characters in public" (@jackyie, 2015, August 8). This tweet implies that 'identification of similar problems' can, in some cases, lead to criticism toward society itself.

\subsubsection{Background checking of the target}

Another category called 'background checking of the target' designates a collective communication process where online users discuss, by exchanging information, whether the target has previously caused any other trouble. Citing articles, rumors, and experiences related to the target, participants' attention, in this process, shifts from the event itself to the target's career or reputation. In the case 5, for example, this type of communication was frequently observed. This Enjo case was triggered by a tweet with a video, in which a college football player of Nihon University made a violent tackle. Although the player was attacked on social media at the beginning, the participants gradually began to criticize his coaches as articles indicated that they had forced him to make the tackle. In addition, Nihon University was socially criticized since its response to online criticism had some problems. In this case, the participants not only discussed the event (compulsion of a violent tackle by college football coaches) but also exchanged information about the background of the target (football coaches, Nihon University). This kind of communication includes a tweet such as: "this is an article released from VICE three years ago. In this article, there is a photograph of the current chairman of Nihon University, Tanaka Hidetoshi, and the top of a Japanese mafia organization, Tsukasa Shinobu, together. It says that Tanaka Hidetoshi has intimidated staff members at the university with this photo"(@HNamachiri, 2018, May 23).

When past target-related issues are discovered and shared through social media or mass media, criticism toward the target intensifies. Even if Enjō occurs, it does not necessarily lead to severe bashing of the target since the problem might be caused unintentionally. However, in cases where 'background checking of the target' reveals his/her negative reputation, participants tend to associate the event with intrinsic characteristics of the target and anticipate that he/she is intrinsically evil. The participants, then, would be more motivated to severely attack the target.

\section{Discussion and conclusions}

This paper analyzes communication processes among Enjō participants on Twitter in order to grasp the dynamics of Enjo phenomena, which few studies have previously revealed. As a result, this article reveals that when Enjō occurs, participants tend to collectively communicate with each other to construct the definition of the problem by reconstructing the event and imparting their own interpretation to it. In addition, the focal point of their discussion frequently expands to other issues such as similar problems to the original one or the targets background (see Figure 1).

These findings have various implications. First, whether participants can clearly define the problem of concern through communication seems to affect the course of the Enjo incident. When the definition of the problem by the participants is convincing, Enjō may disseminate widely among users and cause intense criticism toward the target. On the other hand, if participants cannot provide clear definition of the problem, people may hesitate to criticize the target and spend more time to discuss what and whom to attack. Such control of Enjō phenomena by collective communication and discussion implies the importance of the perceptual aspects of Enjō. Though most people and researchers have argued that Enjo is an emotional phenomenon where individuals reflexively post 
aggressive comments with anger, the result suggests that participants actually discuss what the problem is and how serious it is, and based on the discussion, they judge whether or not to blame the target. Of course, this does not mean that the participants are always rational and criticize the target based on accurate information in Enjo cases. We can easily find cases where people seem highly emotional and fake news quickly spreads on social media. It is then important to note that Enjō is neither a totally rational phenomenon nor a totally emotional phenomenon but integrates both aspects. The current article especially focused on the rational, or perceptual aspects of online firestroming and revealed the dynamics of Enjo.

Figure 1. The generated categories, which represent the types of communication, developed in five Enjō cases analyzed. The arrows do not denote the passage of time but represent the flow of discussion

\section{Definition of the problem Expansion of the problem}

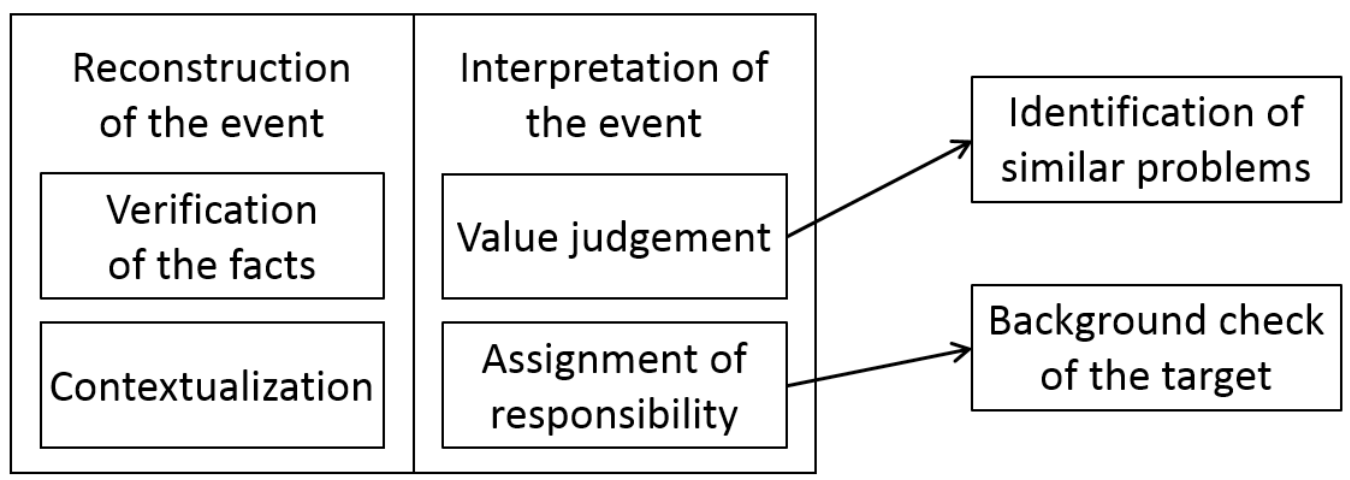

Author's own creation.

Second, the expansion of Enjō has two orientations, which can control the aggressiveness of the participants. The criticism by participants, as shown in the results, can expand beyond the original event, and the participants may begin to attack related issues such as similar problems in society ('identification of similar problems') or past trouble caused by the target ('background checking of the target'). Through 'identification of similar problems,' people begin to perceive that the problem is not peculiar but socially ubiquitous, and is ascribed to social conditions or social systems. Therefore, this kind of escalation process can be called "social problematization." On the other hand, 'background checking of the target' may lead participants to find target-related problems and focus on the deviant identity of the target. In such case, this escalation can be labeled as "villainization." While social problematization can weaken the participants' aggressiveness toward the target by diverting their focus from the target to society, villainization can increase hate and disgust toward the target by amplifying the negative images of the target. This argument needs to be discussed further in future works.

Though this paper discusses important issues related to online firestorms, there are some limitations. First, the coverage of this article is limited to Enjō phenomena on Twitter in Japan and the findings cannot be generalized to different environments. The structure of a platform or the culture of a country is considered to affect the processes of communication in Enjō; therefore we may find different patterns of communication in other social media or other regions. Second, this research generates categories of communication in Enjō, but does not produce a theory or a hypothesis which specifies the causal relationships among such categories. In order to achieve that, it would be required for future research to analyze more cases and conduct systematic comparisons that control variables. This study could be positioned as the first step to generate a theory of the process of Enjō. Third, this article does not pay enough attention to the roles of mass media or news me- 
dia in the formation process of Enjo though previous research has indicated that these media have major influence on the course of Enjō phenomena (Fujishiro, 2014). In spite of these limitations, this article provides a foundation for the further understanding of important issues related to online firestorming.

\section{References}

Adachi, Y. \& Takeda, F. (2016). Characteristics and stock prices of firms flamed on the Internet: The evidence from Japan. Electronic Commerce Research and Applications, 17 (2014), 49-61. https://doi.org/10.1016/j.elerap.2016.03.001

Asch, S. E. (1952). Social Psychology. Englewood Cliffs, N.J., US: Prentice-Hall.

Becker, H. S. (1963). Outsiders: Studies in the Sociology of Deviance. New York, US: The Free Press.

Blumer, H. G. (1969). Symbolic Interactionism: Perspective and Method. Englewood Cliffs, N.J., US: Prentice Hall.

Buckels, E. E., Trapnell, P. D. \& Paulhus, D. L. (2014). Trolls just want to have fun. Personality and Individual Differences, 67, 97-102. https://doi.org/10.1016/j.paid.2014.01.016

Durkheim, É. (1978). The rules of sociological method (T. Miyajima, Trans.) [in Japanese]. Tokyo, Japan: Iwanami-Shoten. (Translate Les regles de la methode sociologique, 1960, 14th ed., Paris, France: Presses Universitaires de France.)

eltes. (2017). Media trend in Enjō [in Japanese]. Retrieved from Digital Risk Research Institute: https://www.eltes-orm.com/

Erikson, K. T. (1966). Wayward Puritans: A study in the sociology of deviance. New York, US: Wiley.

Fujishiro, H. (2014). The age when everyone is journalist: middle media's roles and problems. In K. Endo (Ed.). The journalism in complexedly-mediated societies: Do social media change public nature? (pp. 103-123) [in Japanese]. Tokyo, Japan: Tokyo Denki University Press.

Glaser, B. G. \& Strauss, A. L. (1965). Awareness of Dying. New York, US: Aldine Publishing Company.

Glaser, B. G. \& Strauss, A. L. (1967). The Discovery of Grounded Theory: Strategies for Qualitative Research. Chicago, US: Aldine Publishing Company.

Hogetsu, M. (2004). Sociology of deviance and control [in Japanese]. Tokyo, Japan: Yuhikaku.

Kawakami, N. (2014). A cultural area formed on the Internet. In N. Kawakami (Ed.). The culture created by the Internet: The age when anyone can express themselves on the web (pp. 9-40) [in Japanese]. Tokyo, Japan: KADOKAWA.

Kiesler, S., Siegel, J. \& McGuire, T. (1984). Social Psychological Aspects of Computer-Mediated Communication. American Psychologist, 39, 1123-1134. https://doi.org/10.1

037/0003-066X.39.10.1123

Kobayashi, N. (2011). Collection of Enjō cases on social media [in Japanese]. Tokyo, Japan: Nikkei-BP. 
Korenaga, R. (2008). Communication in cyber space: Why is the Internet in flames. In Y. Hashimoto (Ed.), Media and communication studies (pp. 162-179) [in Japanese]. Tokyo, Japan: Taisyukan- Syobō.

Miura, A. (2010). Communication in digital media. In M. Aikawa \& J. Takai (Eds.), Communication and interpersonal relationships (pp. 20-36) [in Japanese]. Tokyo, Japan: SeishinSyobō.

Morio, H. (2009). CMC and interpersonal relationships. In A. Miura, H. Morio, \& Y. Kawaura (Eds.), The frontier of Internet psychology: Individual, group, and society (pp. 88-115) [in Japanese]. Tokyo, Japan: Seishin- Syobō.

Nakagawa, J. (2010). Crazy people who participate in Enjō: How to cope with mysterious Internet fundamentalists [in Japanese]. Tokyo, Japan: Takarajimasya.

NHK. (2017). Tracking Enjō for 500 days [in Japanese]. Retrieved from NHK NEWS WEB: https://www3.nhk.or.jp/news /special/

Ogiue, C. (2007). Web Enjō: Stampede and potentiality of Internet crowd [in Japanese]. Tokyo, Japan: Chikuma- Syobō.

Reicher, S. D., Spears, R. \& Postmes, T. (1995). A Social Identity Model of Deindividuation Phenomena. In W. Stroebe \& M. Hewstone (Eds.), European Review of Social Psychology (Vol. 6), 161-198. https://doi.org/10.1080/14792779443000049

Sato, I. (2008). The methodology of qualitative analysis: Its principles, methods, and practices [in Japanese]. Tokyo, Japan: Sinyousya.

Scott, C. (1998). To reveal or not to reveal: A theoretical model for anonymous communication. Communication Theory, 8(4), 381-407. https://doi.org/10.1111/j.1468-2885.1998.tb00226.x

Sherif, M. \& Harvey, O. J. (1952). A Study in Ego Functioning: Elimination of Stable Anchorages in Individual and Group Situations. Sociometry, 15(3), 272-305. https://doi.org/10.2307/2785740

Spears, R., Lea, M. \& Postmes, T. (2007). Computer Mediated-Communication and Social Identity. In A. N. Joinson, K. Y. A. McKenna, T. Postmes, \& U. D. Reips (Eds.), The Oxford Handbook of Internet Psychology (pp. 253-272). New York, US: Oxford University Press.

Spector, M. \& Kitsuse, J. I. (1977). Constructing Social Problems. Menlo Park, CA, US: Cummings.

Sproull, L. \& Kiesler, S. (1986). Reducing Social Context Cues: Electronic Mail in Organizational Communication. Management Science, 32, 1492-1512. https://doi.org/1

$0.1287 / \mathrm{mnsc} .32 .11 .1492$

Tanaka, T. (2016). Characteristics of the participants of Enjō and countermeasures for Enjō. Japanese Journal of Clinical Psychiatry [in Japanese], 45(10), 1225-1236.

Tanaka, T. \& Yamaguchi, S. (2016). A study of Enjō: Who perpetrate, and how should we deal with it? [in Japanese]. Tokyo, Japan: Keisō-Syobō.

Toriumi, F. \& Sakaki, T. (2016). Rumor and Enjō: Their diffusion and convergence. In K. Endo (Ed.), Social media and public opinion: Complexed-media shock the world (pp. 220-238) [in Japanese]. Tokyo, Japan: Tokyo Denki University Press. 
Turner, R. H., \& Killian, L. M. (1987). Collective behavior (3rd ed.). Englewood Cliffs, NJ, US: Prentice-Hall.

Yamaguchi, S. (2017). Empirical analysis of the motives for commenting in Enjō. InfoCom REVIEW [in Japanese], (69), 61-74.

Yoshino, H. (2016). Domestic condition and transition of Enjō: Focused on online survey. Corporate Communication Studies [in Japanese], (20), 66-83.

Zimbardo, P. G. (1969). The Human Choice: Individuation, Reason, and Order versus Deindividuation, Impulse, and Chaos. In W. J. Arnold \& D. Levine (Eds.), Nebraska Symposium on Motivation (pp. 237-307). Lincoln, NE, US: University of Nebraska Press.

@aconitine_NEO. (2015, August 8). Female divers have tended to be described sexually and they have objected to it for a long time [Twitter post, in Japanese]. https://twitter.com/aconitine_NEO/ status/630008727689519105

@hasekiyo2468. (2016, August 15). This is terrible [Twitter post, in Japanese]. https://twitter.com/ hasekiyo2468/status/764970138147794944

@ HNamachiri. (2018, May 23). It says that Tanaka Hidetoshi has intimidated staff members at the university with this photo [Twitter post, in Japanese]. https://twitter.com/HNamachiri/ status/999168835495211008

@jackyie. (2015, August 8). In Japan, there exist so many sexual anime characters in public [Twitter post, in Japanese]. https://twitter.com/jackyie/status /62995525041

\section{2}

@KTB_genki. (2015, March 20). The management who decided to release the commercial should be blamed for the problem and resign [Twitter post, in Japanese]. https://twitter.com/KTB_genki/ status/578655593986170880

@)sakuya_little. (2016, August 15). There should be a reason for such a high cost [Twitter post, in Japanese]. https://twitter.com/sakuya_little/status/764949126387642368

@shinmk. (2016, August 17). I do not feel that this problem is somebody else's business. [Twitter post, in Japanese]. https://twitter.com/shinmk/status/76575993792

\section{6}

@ys5project. (2016, August 15). I can understand the accuser's claim but I feel that the company's PC support is satisfying and the cost of its services is relatively reasonable [Twitter post, in Japanese]. https://twitter.com/ys5project/status/764875011

660222464 